\title{
Some 2,5-Disubstitue-1,3,4-Oxadiazoles as New Antioxidants
}

\author{
Nurhan GÜMRÜKÇÜOĞLU ${ }^{1 *}$, Bahar BİLGİN SÖKMEN² \\ ${ }^{1}$ Department of Chemistry, Faculty of Science, Karadeniz Technical University, 61080 Trabzon, Turkey \\ ${ }^{2}$ Department of Chemistry, Faculty of Arts and Sciences, Giresun University, 28049, Giresun, Turkey
}

"Corresponding Author: ngumrukcuoglu@ktu.edu.tr

Received: 18.02 .2019

Accepted: 16.05 .2019

\begin{abstract}
Many heterocyclic compound, a pharmacologically used as the starting compound for the synthesis of new structures which are important. Groups of these azole compounds, due to their various biological activities, in recent years have become common classes of compounds synthesized. Heterocyclic compounds containing five-membered ring, compounds of pharmacological class have entered popular in recent years due to properties. In this study, antioxidant activities of some 2,5-disubstitue-1,3,4-oxadiazoles (1-3) were evaluated for according to ABTS (2,2'-azino-bis(3ethylbenzothiazoline-6-sulphonic acid) diammonium salt), 2,2-diphenyl-1-picrylhydrazyl (DPPH) radical scavenging activities and iron reducing power capacity. The obtained results showed that the synthesized compounds (1-3) had effective antioxidant activities.
\end{abstract}

Key Words: 2,5-Disubstitue-1,3,4-oxadiazoles, Antioxidant, ABTS Radical Scavenging Activity

\section{Yeni Antioksidanlar Olarak Bazı 2,5-Disübstitüye-1,3,4-Oksadiazoller}

\section{Öz}

Birçok heterosiklik bileşik, farmakolojik açıdan önemli olan yeni yapıların sentezi için başlangıç bileşiği olarak kullanılmaktadır. Bunlardan azol gurubu bileşikler, sahip oldukları değişik biyolojik aktivitelerden dolayı son yıllarda sıklıkla sentezlenen bileşik sınıfları haline gelmiştir. Beş üyeli halka içeren heterosiklik bileşikler, farmakolojik özelliklere sahip olmasından dolayı son yıllarda popüler bileşikler sınıfına girmiştir. Bu çalışmada, bazı 2,5-disübstitüye1,3,4-oksadiazollerin (1-3) antioksidan aktiviteleri, ABTS (2,2'-Azino-bis(3-etilbenzenothiazoline-6-sülfonik asid), DPPH (1,1-difenil-2-pikrilhidrazil) radikal giderme aktiviteleri ve demir indirgeme gücü kapasitesine göre incelendi. Elde edilen sonuçlar, sentezlenen bileşiklerin (1-3) etkili antioksidan aktiviteye sahip olduğunu gösterdi.

Anahtar Kelimeler: 2,5-Disübstitüye-1,3,4-oksadiazoller, Antioksidan, ABTS Radikal Giderme Aktivitesi 


\section{Introduction}

In the presence of reactive oxygen species (ROS) known species as chemically reactive molecules can harm carbohydrates, proteins, lipids and loss of cell structure and function, and finally apoptosis or necrosis (Kotaiah et al., 2012; Dasuri et al., 2013). More than 20 years, diseases, such as carcinogenesis, inflammation, neurodegenerative diseases, atherosclerosis and cardiovascular diseases, diabetes, Parkinson and Alzheimer have been associated with high levels of ROS (Nordberg and Arnér, 2001; Uttara et al., 2009; Sosa et al., 2013). For this reason, antioxidant addition has withdrawn enormous interest in recent years in preventing or treating these diseases by counteracting the effect of ROS (Liu et al., 2006; Grodstein et al., 2013).

Oxadiazole is an aromatic heterocyclic ring having the closed formula $\mathrm{C}_{2} \mathrm{H}_{2} \mathrm{~N}_{2} \mathrm{O}$ (Oliveira et al., 2012). Depending on the position of oxygen and nitrogen atom 1,2,4/1,2,3/1,3,4 and 1,2,5 can be found in the structure of oxadiazole. However, 1,3,4 and 1,2,4-oxadiazoles are more studied by researchers because of their important biological and chemical properties (Oliveira et al.,, 2012). Compounds containing 1,3,4-oxadiazole ring in the structure have a broad spectrum of biological activity. Generally antibacterial (Kanthiah et al., 2011; Sridhara et al., 2010; Naveena et al., 2010), antifungal (Jayashankar et al., 2009; Akhter et al., 2008) analgesic (Bharathi et al., 2011), antiinflammatory, antiviral, anticancer (Akhtar et al., 2010; Rostom et al., 2003) and antidiabetic (Shyma et al., 2015) have been shown in recent years. In addition, two diffent compounds containing 1,3,4-oxadiazole ring are now used in clinical medicine. One of them is Raltegravir used as antiretroviral drug, while Zibotentan is used as anti-cancer drug (Figure 1) (Savarino, 2006; James, 2009).

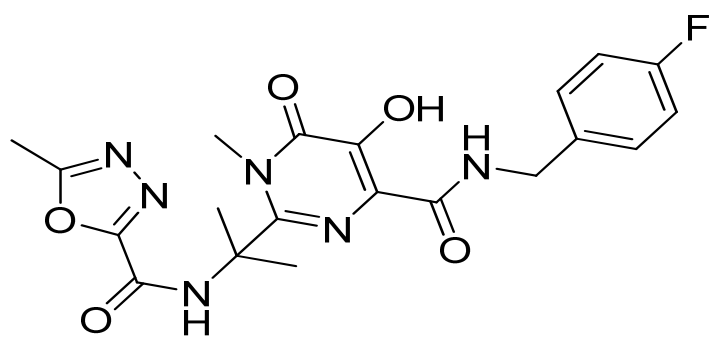

Raltegravir

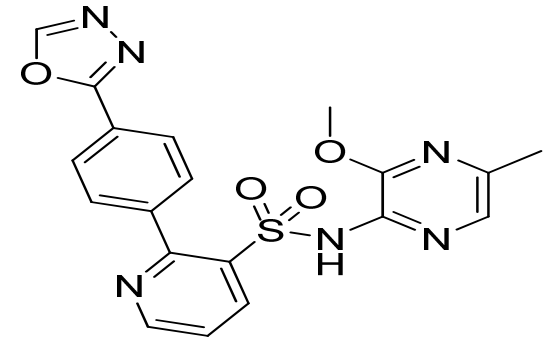

Zibotentan

Figure 1. Structure of Compounds Containing 1,3,4-Oxadiazole Ring

Nonsteroidal anti-inflammatory drugs (NSAIDs) are used to treat inflammatory and painful conditions including joint rheumatism, airway inflammation and fever. These agents actually inhibit the enzyme cyclooxygenase I (COX-1) and cyclooxygenase II (COX-2) and then they cause wounds 
in the gastrointestinal tract, Thromboxane-A2 Synthetase Inhibitors inhibiting TXA2, layer formation and accumulation (Rajak et al., 2009). Combination of these interactions results in irritations and disturbances in the gastrointestinal tract These compounds containing the oxadiazole moiety reduce the amount of gastric acid and inhibit COX/LO. Thus, new agents with minimal side-effects or sideeffects on the gastrointestinal tract containing the oxadiazole moiety have been developed. For example; 1-(4-bromophenyl)-3-(5-(3,4-dimethoxy-phenyl-1,3,4-oxadiazol-2-yl)-propan-1-one was synthesized and showed very good anti-inflammatory activity (Figure 2) (Bala et al., 2010).

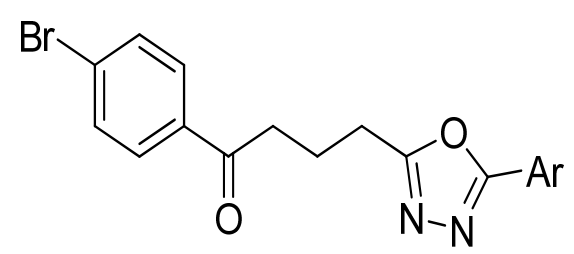

Figure 2. Structure of 1-(4-Bromophenyl)-3-(5-(3,4-dimethoxy-phenyl-1,3,4-oxadiazol-2-yl)-propan-1-one

Besides these, the addition of various functional groups such as $-\mathrm{CH}_{3},-\mathrm{OCH}_{3}$ can create analogs with a larger antioxidant effect than classical molecules (Kade et al., 2009). The aim of current study was to investigate the antioxidant activity of synthesized 2,5-disubstitue-1,3,4-oxadiazoles (1-3). Antioxidant activities of these ligands were evaluated by in vitro assay and compared to the activity of standard compounds 2,5-disubstitue-1,3,4-oxadiazoles were synthesized by Gumrukcuoglu et al. (2007) and Serdar et al. (2007) (Figure 3).

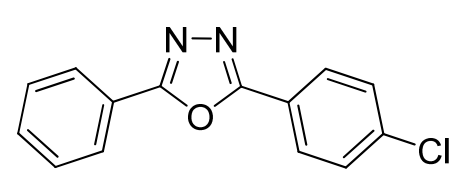

1

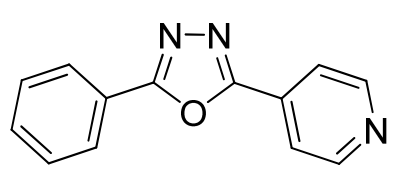

2

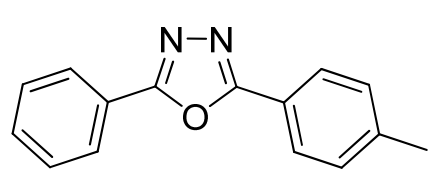

3

Figure 3. Structure of the studied 2,5-disubstitue-1,3,4-oxadiazoles (1-3).

\section{Materials and Methods}

\subsection{General}

All chemicals used in the experiments were purchased from Merck and Fluka. Biological activities of the samples were assayed spectrophotometrically (UV-1240, Shimadzu, Japan). 


\subsection{Antioxidant Activity Assays}

DPPH activity of the oxadiazole derivatives was determined by Brand Williams et al. (1995). The ABTS radical scavenging activity of the oxadiazole derivatives was measured according to the method described by Arnao et al. (2001). The reducing power of the oxadiazole derivatives was examined according to the method of Oyaizu (1986).

\section{Findings and Discussion}

DPPH is generally used as a reagent to appraise free radical scavenging activity of antioxidant substances (Oyaizu, 1986). The DPPH radical scavenging activity of 2,5-disubstitue-1,3,4-oxadiazole derivatives are presented in Table 1. As standard antioxidant was used Trolox (6-hydroxy-2,5,7,8tetramethylchroman-2-carboxylic acid). All the tested compounds showed DPPH free radical scavenging activities. Their comparable scavenging activities were expressed with $\mathrm{SC}_{50}$ (The potent concentration at which the DPPH radicals were scavenged by 50\%) values in Table 1. Compound 1 had the highest scavenging activity among all the oxadiazole derivatives tested $\left(\mathrm{SC}_{50}=\right.$ $3023 \pm 3878.924 \mu \mathrm{M})$. Compound $\mathbf{2}$ had the lowest scavenging activity among all the samples tested and standards $\left(\mathrm{SC}_{50}=8311 \pm 852.2 \mu \mathrm{M}\right)$.

The ABTS radical scavenging activity of 1,3,4-oxadiazole derivatives compared with Troloxwere showed in Table 1. ABTS radical scavenging activity increased with increasing concentration. Lower $\mathrm{SC}_{50}$ values demonstrate higher ABTS radical scavenging ability. All of the compounds (1348-16883 $\mu \mathrm{M})$ showed lower ABTS radical scavenging activity than Trolox $\left(\mathrm{SC}_{50}=214.55 \pm 24.56 \mu \mathrm{M}\right)$. The highest and lowest activities were found at compounds $\mathbf{1}$ $\left(\mathrm{SC}_{50}=1348 \pm 81.78 \mu \mathrm{M}\right)$ and $2\left(\mathrm{SC}_{50}=16883 \pm 198.4 \mu \mathrm{M}\right)$, respectively.

The reducing powers of the oxadiazole derivatives were studied at different concentrations (250-1000 $\mu \mathrm{g} / \mathrm{mL}$ ), and results were compared with BHT (Butylated hydroxy toluene) (Table 1). In this study, the reducing power of synthesized oxadiazole compounds rised with increasing concentration of samples. The highest and lowest activity were observed at compounds $\mathbf{1}$ and $\mathbf{2}$. The presence of electron donating substituent on both sides of the 1,3,4-oxadiazole ring enhances the activity and electron withdrawing groups decreases. This result is consistent with the article by Kanthiah et al (2011). 
Table 1. The antioxidant activities of 2,5-disubstitue-1,3,4-oxadiazole derivatives and standards (1-3).

\begin{tabular}{|c|c|c|c|}
\hline Compounds & $\operatorname{DPPH~SC}_{50}(\mu \mathrm{M})^{*}$ & $\operatorname{ABTS~SC}_{50}(\mu \mathrm{M})^{*}$ & $\begin{array}{c}\text { Reducing Power } \\
\text { Absorbance* }\end{array}$ \\
\hline \multirow{5}{*}{1} & \multirow{5}{*}{$8311 \pm 852.2$} & \multirow{4}{*}{$16883 \pm 198.4$} & $0.054 \pm 0.006$ \\
\hline & & & $0.073 \pm 0.008$ \\
\hline & & & $0.097 \pm 0.008$ \\
\hline & & & $0.115 \pm 0.009$ \\
\hline & & \multirow{5}{*}{$15124 \pm 169.1$} & $0.09 \pm 0.008$ \\
\hline \multirow[t]{4}{*}{2} & \multirow[t]{4}{*}{$6747 \pm 192.3$} & & $0.111 \pm 0.004$ \\
\hline & & & $0.131 \pm 0.006$ \\
\hline & & & $0.148 \pm 0.008$ \\
\hline & & & $0.213 \pm 0.012$ \\
\hline \multirow[t]{3}{*}{3} & \multirow[t]{3}{*}{$3023 \pm 389.3$} & \multirow[t]{3}{*}{$1348 \pm 81.78$} & $0.272 \pm 0.02$ \\
\hline & & & $0.342 \pm 0.042$ \\
\hline & & & $0.417 \pm 0.008$ \\
\hline \multirow[t]{2}{*}{ Trolox } & \multirow[t]{2}{*}{$158.15 \pm 11.05$} & \multirow[t]{2}{*}{$249.47 \pm 21.34$} & - \\
\hline & & & $0.162 \pm 0,012$ \\
\hline \multirow[t]{3}{*}{ BHT } & \multirow[t]{3}{*}{-} & \multirow[t]{3}{*}{-} & $0.205 \pm 0.018$ \\
\hline & & & $0.274 \pm 0.021$ \\
\hline & & & $0.311 \pm 0.025$ \\
\hline
\end{tabular}

*Values were the means of three replicates \pm Standard deviation (SD).

\section{Conclusions}

In this study, the results showed that the synthesized 2,5-disubstitue-1,3,4-oxadiazole derivatives (1-3) had antioxidant activities. Consequently, these derivatives could be used as a source of antioxidant in pharmaceutical, cosmetic and agriculture industries.

\section{References}

Akhtar, T., Hameed, S., Al-Masoudi, N.A., Loddo, R., Colla, P.L. (2010). In Vitro Antitumor and Antiviral Activities of New Benzothiazole and 1,3,4-oxadiazole-2-thione Derivatives. Acta Pharmazie, 58, 135 149.

Akhter, M., Husain, A., Azad, B., Ajmal, M.(2008). Aroylpropionic Acid Based 2,5- Disubstituted-1,3,4oxadiazoles: Synthesis and Their Anti-Inflammatory and Analgesic Activities. European Journal of Medicinal Chemistry, 44, 2372-2378.

Arnao, M.B., Cano, A., Acosta, M. (2001). The hydrophilic,and lipophilic contribution to total antioxidant activity. Food Chemistry, 73, 239-244.

Bala, S., Kamboj, S., Kumar, A. (2010). Heterocyclic 1,3,4-oxadiazole compounds with diverse biological activities, Journal of Pharmacy Research, 3(12), 2993-2997.

Bharathi, D., Hemalatha, S., Devadass, G., Kumar, P.R., Shanmugasundaram, P., Aanandhi, M.V.(2010). Synthesis, Characterisation and in-vitro Antiinflammatory and Anthelmintic activities of 1,3,4Oxadiazole derivatives. International Journal of Chem Tech Research, 2(4), 1867-1870.

Brand-Williams, W., Cuvelier, M. V., Berset, C. (1995). Use of a Free Radical Method to Evaluated Antioxidant Activity. LWT-Food Science Technology, 26, 25-30.

Dasuri, K., Zhang, L., Keller, J.N. (2013). Oxidative stress, neurodegeneration, and the balance of protein degradation and protein synthesis, Free Radical Biology \& Medicine, 62, 170-185.

Grodstein, F., O'Brien, J., Kang, J. H., Dushkes, R., Cook, N. R., Okereke, O., Manson, J.E., Glynn, R.J., Buring, J.E., Gaziano, M., Sesso, H.D. (2013). Long-term multivitamin supplementation and cognitive function in men: A randomized trial. Annals of Internal Medicine, 159, 806-814. 
Gumrukcuoglu, N., Serdar, M., Çelik, E., Sevim, E., Demirbaş N. (2007). Synthesis and Antimicrobial Activities of Some New 3,5-dialkyl-1,2,4-Triazole Derivatives. Turkish Journal of Chemistry, 31, 335348.

James, N.D., Growcott, J.W. (2009). Zibotentan. Drugs Future, 34, 624-633.

Jayashankar, B., Rai, K.M.L., Baskaran, N., Sathish, H.S. (2009). Synthesis and Pharmacological Evaluation of 1,3,4-Oxadiazole Bearing Bis(Heterocycle) Derivatives as Anti-inflammatory and Analgesic Agents. European Journal of Medicinal Chemistry, 44, 3898-902.

Kade, I.J., Paixão, M.W., Rodrigues, O.E.D., Ibukun, E.O., Braga, A.L., Zeni, G., Nogueira, C.W., Rocha, J.B.T. (2009). Studies on the antioxidant effect and interaction of diphenyl diselenide and dicholesteroyl diselenide with hepatic d-aminolevulinic acid dehydratase and isoforms of lactate dehydrogenase, Toxicology in Vitro, 23, 14-20.

Kanthiah, S., Kalusalingam, A., Velayutham, R., Vimala, A.T., Beyatricks, J. (2011). 5-(2-Aminophenyl)1,3,4-oxadiazole2(3H)-thione Derivatives Synthesis, characterization and antimicrobial evaluation. International Journal of Pharmaceutical Sciences Review and Research, 6(1), 64-67.

Kotaiah, Y.; Harikrishna, N.; Nagaraju, K.; Rao, C.V. 2012, Synthesis and antioxidant activity of 1,3,4oxadiazole tagged thieno[2,3-d]pyrimidine derivatives, European Journal of Medicinal Chemistry, 58, 340- 345.

Liu, S., Lee, I. M., Song, Y., Van Denburgh, M., Cook, N. R., Manson, J. E., Buring, J.E. (2006). Vitamin E and risk of type 2 diabetes in the women's health study randomized controlled trial. Diabetes, 55, 28562862.

Naveena, C.S., Boja, P., Kumari, N.S. (2010). Synthesis, Characterization and Antimicrobial Activity of Some Disubstituted 1,3,4-Oxadiazoles Carrying 2-(Aryloxymethyl)phenyl Moiety. European Journal of Medicinal Chemistry, 45, 4708-4719.

Nordberg, J.; Arnér, E. S. J. 2001, Reactive oxygen species, antioxidants, and the mammalian thioredoxin system, Free Radical Biology and Medicine, 31(11), 1287-1312.

Oliveira, C., Lira, B., Barbosa-Filho, J., Lorenzo, J.G.F., AthaydeFilho, P. (2012). Synthetic Approaches and Pharmacological Activity of 1,3,4-Oxadiazoles: A Review of the Literature from 2000-2012. Molecules, 17, 10192-10291.

Oyaizu, M.(1986). Studies on products of browning reactions: Antioxidative activities of products of browning reaction prepared from glucosamine. The Japanese Journal of Nutrition and Dietetics, 44, 307-315.

Rajak, H., Dhar, M., Kharya ve Mishra, P. (2009). Biologically Active 2,5-Disubstituted-1,3,4-Oxadiazoles. International Journal of Pharmaceutical Sciences and Nanotechnology, 2, 390-406.

Rostom, S.A.F., Shalaby, M.A., ElDemellawy, M.A. (2003). Synthesis of New 1-(4- Chlorophenyl)-4hydroxy-1H-pyrazole- 3-carboxylic Acid Hydrazide Analogs and Some Derived Ring Systems. A Novel Class of Potential Antitumor and Anti-HCV Agents. European Journal of Medicinal Chemistry, 38, 959-74.

Savarino, A. (2006). A Historical Sketch of the Discovery and Development of HIV-1 Integrase Inhibitors. Expert Opinion on Investigational Drugs, 15, 1507-1522.

Serdar, M., Gumrukcuoglu, N., Karaoğlu, Ş. A., Demirbaş, N. (2007). Synthesis of Some Novel 3,5-Diaryl1,2,4-Triazole Derivatives and Investigation of Their Antimicrobial Activities, Turkish Journal of Chemistry, 31, 315-326.

Shyma, P.C., Balakrishna, K., Peethambar, S.K., Vijesh, A.M. (2015). Synthesis, Characterization, Antidiabetic and Antioxidant Activity of 1,3,4-oxadiazole Derivatives Bearing 6-Methyl Pyridine Moiety, Der Pharma Chemica, 7(12), 137-145.

Sosa, V., Moliné, T., Somoza, R., Paciucci, R., Kondoh, H., LLeonart, M.E. (2013). Oxidative stress and cancer: An overview. Ageing Research Reviews, 12, 376-390.

Sridhara, A.M., Reddy, K.R.V., Keshavayya, J., Goud, P.S.K., Somashekar, B.C., Bose, P. (2010). Synthesis and Antimicrobial Activity of 2-Substituted[4-(1,3,4-Oxadiazol-2-yl methyl)] phthalazin1(2H)-one derivatives, European Journal of Medicinal Chemistry, 45, 4983-4989.

Uttara, B., Singh, A.V., Zamboni, P., Mahajan, R.T. (2009). Oxidative Stress and Neurodegenerative Diseases: A Review of Upstream and Downstream Antioxidant Therapeutic Options, Current Neuropharmacology, 7(1), 65-74. 